\section{Efficacy of Improved Hydrogen Peroxide against Important Healthcare- Associated Pathogens}

\author{
William A. Rutala, PhD, MPH; ${ }^{1,2}$ \\ Maria F. Gergen, MT (ASCP); ${ }^{1}$ \\ David J. Weber, MD, MPH ${ }^{1,2}$
}

This study was designed to test in vitro efficacy of 2 improved hydrogen peroxide (HP) products against 3 standard HP products and 1 quaternary ammonium compound. Improved HP is significantly superior to standard HP at the same concentration and can be used for disinfection of environmental surfaces or noncritical patient care items.

Infect Control Hosp Epidemiol 2012;33(11):1159-1161

An improved hydrogen peroxide-based technology has been introduced into health care for disinfection of noncritical environmental surfaces and patient equipment ${ }^{1}$ and highlevel disinfection of semicritical equipment such as endoscopes. ${ }^{2-4}$ Improved hydrogen peroxide (HP) contains very low levels of anionic and/or nonionic surfactants in an acidic product, which act with HP to produce microbicidal activity. This combination of ingredients speeds the antimicrobial activity of hydrogen peroxide and cleaning efficiency. ${ }^{3,4} \mathrm{Im}$ proved HP is considered safe for humans and equipment and benign for the environment. In fact, improved HP has the lowest Environmental Protection Agency (EPA) toxicity category (ie, category IV) based on its oral, inhalation, and dermal toxicity, which means it is practically nontoxic and not an irritant. ${ }^{1,3,5}$ It is prepared and marketed by several companies in various concentrations (eg, $0.5 \%-7 \%$ ) and different products may use different terminology for these products such as "accelerated" or "activated." Lower concentrations (ie, $0.5 \%, 1.4 \%$ ) are designed for the low-level disinfection of noncritical environmental surfaces and patient care objects while the higher concentrations (ie, $>2 \%$ ) can be used as high-level disinfectants for semicritical medical devices (eg, endoscopes).

The purpose of the study was to evaluate the antimicrobial activity of new HP formulations designed for disinfection on noncritical environmental surfaces and noncritical patient care equipment with older standard HP formulations and a quaternary ammonium compound (QUAT).

\section{METHODS}

\section{Disinfectants Tested}

We tested the following disinfectants: A456-II a QUAT (Ecolab) at $1: 256$; Clorox Healthcare Hydrogen Peroxide Cleaner
Disinfectant (Clorox), undiluted; hydrogen peroxide (Owens and Minor) at undiluted (3.0\%), 1.4\%, and $0.5 \%$; and Oxivir TB (Johnson Diversey), undiluted.

\section{Test Organisms}

We tested 3 epidemiologically important pathogens: a community-acquired methicillin-resistant Staphylococcus aureus strain (MRSA; USA300), vancomycin-resistant Enterococcus (VRE; ATCC 51299), and multidrug-resistant (MDR) Acinetobacter baumannii (clinical strain).

Our test organism suspensions were prepared fresh daily by plating each organism to sheep blood agar (SBA; Remel) and incubating it at $37^{\circ} \mathrm{C}$ for approximately 18 hours before each run. Immediately before each run, $0.5 \mathrm{McFarland}$ standard suspensions were prepared from these plates separately for each organism in trypticase soy broth (TSB; Remel). To simulate loading with organic material, fetal calf serum (Remel) at a final concentration of 5\% was added to the TSB.

\section{Disinfectant Testing}

The second tier of a quantitative carrier test, a standard of ASTM International, was used to determine the bactericidal activity of the formulations. ${ }^{6}$ In this test, stainless steel disks (1-cm diameter $\times 0.7 \mathrm{~mm}$ thick; Muzeen and Blythe) were contaminated with $10 \mu \mathrm{L}$ of test suspension $\left(10^{3}-10^{6}\right.$ colonyforming units [CFUs] of the test organism). To detect lowlevel antimicrobial activity (ie, $<3-\log _{10}$ reduction), a lower inoculum $\left(10^{3}\right.$ CFUs per carrier) was used when the disinfectant showed no bactericidal activity at the higher microbial load. One disk each was placed, with contaminated side up, at the bottom of a sterile $20-\mathrm{mL}$ glass vial, covered with 50 $\mu \mathrm{L}$ of the test disinfectant and held for the desired contact time (eg, 30 seconds, 1 minute) at room temperature $\left(20^{\circ} \pm\right.$ $2^{\circ} \mathrm{C}$ ). We did not test times greater than 1 minute, which may have been part of the label claim (eg, 10 minutes) because these longer times are difficult to achieve in practice. At the end of the contact time, the action of the disinfectant was stopped by the addition of $9.95 \mathrm{~mL}$ neutralizer $(0.85 \% \mathrm{NaCl}$ $+0.1 \%$ Tween $80 \%+3 \%$ glycine [except for quaternary ammonium compound used $1 \%$ sodium thiosulfate] at $\mathrm{pH}=7.2-7.4)$. The contents of the vial were vortexed on high for 1 minute to elute the inoculum from the surface of the disks. The eluates and 3 washes of the vials with sterile saline were passed through a membrane filter (Savur analytical funnel containing a $0.22-\mu \mathrm{L}$ filter; GE Water and Process Technologies). After the vial had been adequately rinsed, the sides of the analytical funnel were rinsed with $40 \mathrm{~mL}$ of sterile saline. Each filter was aseptically placed on the surface of SBA and incubated at $37^{\circ} \mathrm{C}$ for 48 hours. After 48 hours, the CFUs were counted and the $\log _{10}$ reductions were calculated. 


\section{RES ULTS}

The bactericidal activities of the disinfectants tested are displayed in Table 1, and the statistical analysis is summarized in Table 2. The 2 improved HP products had similar effectiveness (eg, $>6-\log _{10}$ reduction within 30 seconds) against the test organisms and were significantly superior to all 3 concentrations of HP. The improved HP products were superior or similar to the QUAT tested. The standard HP products (ie, $3.0 \%, 1.4 \%, 0.5 \%)$ generally had similar bactericidal activity. Finally, the QUAT was significantly superior or similar to the standard HP products. These relationships held true regardless of the presence or absence of fetal calf serum and contact time.

\section{I S C US S I O N}

There is excellent evidence in the scientific literature that environmental contamination plays an important role in the transmission of MRSA, VRE, Clostridium difficile, and Acinetobacter. ${ }^{7,8}$ These pathogens have been demonstrated to persist in the environment for days (and in some cases, months) to frequently contaminate the environmental surfaces in rooms of colonized or infected patients, to transiently colonize the hands of healthcare personnel, to be transmitted by healthcare personnel, and to cause outbreaks in which environmental transmission was deemed to play a role. Furthermore, admission to a room in which the previous patient had been colonized or infected with MRSA, VRE, C. difficile, or Acinetobacter has been shown to be a risk factor for the newly admitted patient to develop colonization or infection. ${ }^{7,8}$ Although environmental contamination has been demonstrated as an important component of patient-to-patient transmission of these pathogens, the effectiveness of disinfectants to clean contaminated surfaces has not been completely assessed.

It has long been recommended in the United States that environmental surfaces in patient rooms be cleaned and disinfected on a regular basis (eg, daily, 3 times per week), when surfaces are visibly soiled, and after patient discharge. ${ }^{9}$ Disinfection is generally performed using a 1-step process with an EPA-registered hospital disinfectant such as a QUAT. We compared the bactericidal activity of a QUAT to 2 new, improved HP products. The improved HP appeared to be superior or similar to the QUAT tested. When the 2 improved HP products were compared to $0.5 \%, 1.4 \%$, and $3 \%$ HP formulations, the improved HP-based environmental surface disinfectants proved to be more effective ( $>6-\log _{10}$ reduction) and fast-acting (30-60 seconds) microbicides in the presence of a soil load (to simulate the presence of body fluids) than commercially available HP. Only 30-60-second contact time was studied because

TA B LE 1. Bactericidal Activity of Disinfectants ( $\log _{10}$ Reduction) with a Contact Time of 30 Seconds or 1 Minute at $20^{\circ} \mathrm{C}$ with and without Fetal Calf Serum (FCS)

\begin{tabular}{|c|c|c|c|c|c|c|}
\hline Organism & $\begin{array}{l}\text { Oxivir TB } \\
\left(0.5 \% \mathrm{H}_{2} \mathrm{O}_{2}\right)\end{array}$ & $0.5 \% \mathrm{H}_{2} \mathrm{O}_{2}$ & $\begin{array}{l}\text { CHHPCD } \\
\left(1.4 \% \mathrm{H}_{2} \mathrm{O}_{2}\right)\end{array}$ & $1.4 \% \mathrm{H}_{2} \mathrm{O}_{2}$ & $3.0 \% \mathrm{H}_{2} \mathrm{O}_{2}$ & $\begin{array}{l}\text { A456-II } \\
\text { (QUAT) }\end{array}$ \\
\hline \multicolumn{7}{|c|}{$\begin{array}{l}\sim 10^{6} \text { inoculum, contact time }=1 \text { minute, } \\
\text { no } 5 \% \text { FCS }\end{array}$} \\
\hline MRSA & $>6.62$ & $\leq 4.04$ & $>6.54$ & $\leq 4.04$ & $\leq 4.04$ & 5.55 \\
\hline VRE & $>6.34$ & $\leq 3.61$ & $>6.13$ & $\leq 3.61$ & $\leq 3.61$ & 4.58 \\
\hline MDR A. baumannii & $>6.76$ & $\leq 4.28$ & $>6.76$ & $\leq 4.28$ & $\leq 4.28$ & $>6.76$ \\
\hline \multicolumn{7}{|c|}{$\begin{array}{l}\sim 10^{6} \text { inoculum, contact time }=30 \text { seconds, } \\
\text { no } 5 \% \text { FCS }\end{array}$} \\
\hline MRSA & $>6.64$ & NT & $>6.64$ & NT & $\leq 4.16$ & $\leq 4.16$ \\
\hline VRE & $>6.28$ & NT & $>6.28$ & NT & $\leq 3.80$ & $\leq 3.80$ \\
\hline MDR A. baumannii & $>6.76$ & NT & $>6.76$ & NT & $\leq 4.28$ & 6.11 \\
\hline \multicolumn{7}{|c|}{$\begin{array}{l}\sim 10^{3} \text { inoculum, contact time }=1 \text { minute, } \\
\text { no } 5 \% \text { FCS }\end{array}$} \\
\hline MRSA & $>3.71$ & $\leq 1.23$ & $>3.71$ & $\leq 1.23$ & $\leq 1.23$ & $>3.71$ \\
\hline VRE & $>3.26$ & 1.45 & $>3.26$ & NT & 1.40 & $>3.26$ \\
\hline MDR A. baumannii & $>3.53$ & $\leq 1.05$ & $>3.53$ & 1.75 & $>3.53$ & $>3.53$ \\
\hline \multicolumn{7}{|c|}{$\begin{array}{l}\sim 10^{6} \text { inoculum, contact time }=1 \text { minute, } \\
5 \% \text { FCS present }\end{array}$} \\
\hline MRSA & $>6.72$ & NT & $>6.72$ & NT & $\leq 4.24$ & $\leq 4.24$ \\
\hline VRE & $>6.26$ & NT & $>6.26$ & NT & $\leq 3.78$ & $\leq 3.78$ \\
\hline MDR A. baumannii & $>6.56$ & NT & $>6.56$ & NT & $\leq 4.08$ & $>6.56$ \\
\hline
\end{tabular}

Nоте. Individual mean values may have the same result because the same inoculums on the same day may have been run against multiple disinfectants. If complete killing occurred, the minimum inactivation would equal the initial inoculum. Some results reported as "greater than X" because complete killing of the inoculums occurred. A. baumannii, Acinetobacter baumannii; CHHPCD, Clorox Healthcare Hydrogen Peroxide Cleaner Disinfectant; MDR, multidrug-resistant; MRSA, methicillin-resistant Staphylococcus aureus; NT, not tested; VRE, vancomycin-resistant Enterococcus. 
T A B LE 2. Comparative Efficacy of Improved Hydrogen Peroxide (HP), Standard HP, and a Quaternary Ammonium Compound

\begin{tabular}{|c|c|c|c|c|c|c|}
\hline & Oxivir TB & $0.5 \% \mathrm{HP}$ & CHHPCD & $1.4 \% \mathrm{HP}$ & $3.0 \% \mathrm{HP}$ & A456-II \\
\hline Oxivir TB & $\ldots$ & $\begin{array}{l}\text { Oxivir TB > } \\
0.5 \% \text { HP }\end{array}$ & $\begin{array}{l}\text { Oxivir TB = } \\
\text { CHHPCD }\end{array}$ & $\begin{array}{l}\text { Oxivir } \mathrm{TB}> \\
1.4 \% \mathrm{HP}\end{array}$ & $\begin{array}{l}\text { Oxivir } \mathrm{TB}> \\
3.0 \% \mathrm{HP}^{\mathrm{a}}\end{array}$ & $\begin{array}{l}\text { Oxivir } \mathrm{TB}>\text { or } \\
=\mathrm{A} 456-\mathrm{II}\end{array}$ \\
\hline $0.5 \% \mathrm{HP}$ & $\begin{array}{l}\text { Oxivir TB > } \\
0.5 \% \text { HP }\end{array}$ & $\ldots$ & $\begin{array}{l}\text { CHHPCD > } \\
0.5 \% \text { HP }\end{array}$ & $\begin{array}{l}1.4 \% \mathrm{HP}>\text { or } \\
=0.5 \% \mathrm{HP}\end{array}$ & $\begin{array}{l}3.0 \% \mathrm{HP}>\text { or } \\
=0.5 \% \mathrm{HP}\end{array}$ & $\begin{array}{l}\text { A456-II > or } \\
=0.5 \% \mathrm{HP}\end{array}$ \\
\hline CHHPCD & $\begin{array}{l}\text { Oxivir } \mathrm{TB}= \\
\text { CHHPCD }\end{array}$ & $\begin{array}{l}\text { CHHPCD > } \\
0.5 \% \text { HP }\end{array}$ & $\ldots$ & $\begin{array}{l}\mathrm{CHHPCD}> \\
1.4 \% \mathrm{HP}\end{array}$ & $\begin{array}{l}\mathrm{CHHPCD}> \\
3.0 \% \mathrm{HP}^{\mathrm{a}}\end{array}$ & $\begin{array}{l}\text { CHHPCD }>\text { or } \\
=\mathrm{A} 456-\mathrm{II}\end{array}$ \\
\hline $1.4 \% \mathrm{HP}$ & $\begin{array}{l}\text { Oxivir TB > } \\
1.4 \% \mathrm{HP}\end{array}$ & $\begin{array}{l}1.4 \% \mathrm{HP}>\text { or } \\
=0.5 \% \mathrm{HP}\end{array}$ & $\begin{array}{l}\text { CHHPCD > } \\
1.4 \% \text { HP }\end{array}$ & $\ldots$ & $\begin{array}{l}3.0 \% \mathrm{HP}>\text { or } \\
=1.4 \% \mathrm{HP}\end{array}$ & $\begin{array}{l}\mathrm{A} 456-\mathrm{II}>\text { or } \\
=1.4 \% \mathrm{HP}\end{array}$ \\
\hline $3.0 \% \mathrm{HP}$ & $\begin{array}{l}\text { Oxivir TB > } \\
3.0 \% \mathrm{HP}^{\mathrm{a}}\end{array}$ & $\begin{array}{l}3.0 \% \mathrm{HP}>\text { or } \\
=0.5 \% \mathrm{HP}\end{array}$ & $\begin{array}{l}\text { CHHPCD > } \\
3.0 \% \mathrm{HP}^{\mathrm{a}}\end{array}$ & $\begin{array}{l}3.0 \% \mathrm{HP}>\text { or } \\
=1.4 \% \mathrm{HP}\end{array}$ & $\ldots$ & $\begin{array}{l}\text { A } 456-\mathrm{II}>\text { or } \\
=3.0 \% \mathrm{HP}\end{array}$ \\
\hline A456-II & $\begin{array}{l}\text { Oxivir TB > or } \\
=\text { A456-II }\end{array}$ & $\begin{array}{l}\text { A456-II > or } \\
=0.5 \% \mathrm{HP}\end{array}$ & $\begin{array}{l}\text { CHHPCD > or } \\
=\text { A456-II }\end{array}$ & $\begin{array}{l}\text { A456-II > or } \\
=1.4 \% \mathrm{HP}\end{array}$ & $\begin{array}{l}\text { A } 456-\mathrm{II}>\text { or } \\
=3.0 \% \mathrm{HP}\end{array}$ & $\ldots$ \\
\hline
\end{tabular}

Nоте. Mean $\log _{10}$ reductions, standard deviations, and $95 \%$ confidence intervals (CI) were calculated using replicate measurements (2-4) for interproduct comparisons. CHHPCD, Clorox Healthcare Hydrogen Peroxide Cleaner Disinfectant; “ $>$," nonoverlapping 95\% CI (ie, means were statistically significant at $P<.05$ ); “=," overlapping 95\% CI (ie, means $P>.05$ ). Environmental Protection Agency (EPA) registration claim for A456-II is 10 minutes, CHHPCD is 30 seconds to 1 minute (bactericidal), Oxivir TB is 1 minute (bactericidal), and standard HP had no EPA registration.

a Except against MDR-Acinetobacter baumannii $\left(10^{3}\right.$ colony-forming units, contact 1 minute, no fetal calf serum).

longer contact times (eg, 10 minutes) are not achievable in clinical practice. It appears, therefore, that the surfactants were able to significantly increase the bactericidal activity of HP. Additionally, the improved HP products have an EPA-registered contact time that is substantially less than most EPAregistered low-level disinfectants.

Standard HP is among the oldest microbicides; however, it is relatively unstable, somewhat slow acting, and has limited antimicrobial activity. The stabilizers, surfactants, and other excipients added to the improved HP formulations have addressed these weaknesses. ${ }^{1}$ Improved HP was also more effective than the tested quaternary ammonium compound and standard HP. Thus, improved HP offers an option for noncritical environmental surfaces and patient equipment, and it addresses some concerns associated with some low-level disinfectants (eg, toxicity, a contact time of 30-60 seconds).

\section{ACKNOWLEDGMENTS}

We acknowledge Dr. Emily Sickbert-Bennett for the statistical analysis.

Potential conflicts of interest. W.A.R. and D.J.W. report that they have been consultants to Clorox and Advanced Sterilization Products within the past 3 years. M.F.G. reports no conflicts of interest relevant to this article. All authors submitted the ICMJE Form for Disclosure of Potential Conflicts of Interest, and the conflicts that the editors consider relevant to this article are disclosed here.

Affiliations: 1. Hospital Epidemiology, University of North Carolina Health Care, Chapel Hill, North Carolina; 2. Division of Infectious Diseases, University of North Carolina School of Medicine, Chapel Hill, North Carolina.

Address correspondence to William Rutala, PhD, MPH, 130 Mason Farm Road, Bioinformatics, Chapel Hill, NC 27599 (brutala@unch.unc.edu).

Received January 25, 2012; accepted May 4, 2012; electronically published September 21, 2012.

(C) 2012 by The Society for Healthcare Epidemiology of America. All rights reserved. 0899-823X/2012/3311-0016\$15.00. DOI: 10.1086/668014

\section{REFERENCES}

1. Omidbakhsh N, Sattar SA. Broad-spectrum microbicidal activity, toxicologic assessment, and materials compatibility of a new generation of accelerated hydrogen peroxide-based environmental surface disinfectant. Am J Infect Control 2006;34:251-257.

2. Sattar SA, Adegbunrin O, Ramirez J. Combined application of simulated reuse and quantitative carrier test to assess high-level disinfection: experiments with an accelerated hydrogen peroxidebased formulation. Am J Infect Control 2002;30:449-457.

3. Omidbakhsh N. A new peroxide-based flexible endoscope-compatible high-level disinfectant. Am J Infect Control 2006;34: 571-577.

4. Omidbakhsh N, Kenny N. An accelerated hydrogen peroxide (AHP)-based fast-acting and reusable microbicide for manual disinfection of heat-sensitive semi-critical medical devices. Can J Infect Control 2008; Spring:81-88.

5. Rochon M, Sullivan N. Products based on accelerated and stabilized hydrogen peroxide: evidence for cleaning and sanitizing efficiency, environmental and human safety and non-corrosiveness. Can J Infect Control 1999;Summer:51-55.

6. Springthorpe SV, Sattar SA. Quantitative carrier tests (QCT) to assess the germicidal activities of chemicals: rationales and procedures. Ottawa: Centre for Research on Environmental Microbiology, 2003.

7. Otter JA, Yezli S, French GL. The role played by contaminated surfaces in the transmission of nosocomial pathogens. Infect Control Hosp Epidemiol 2011;32:687-699.

8. Weber DJ, Rutala WA, Miller MB, Huslage K, Sickbert-Bennett E. Role of hospital surfaces in the transmission of emerging health care-associated pathogens: norovirus, Clostridium difficile, and Acinetobacter species. Am J Infect Control 2010;38:S25-S33.

9. Rutala WA, Weber DJ, Healthcare Infection Control Practices Advisory Committee. Guideline for disinfection and sterilization in healthcare facilities, 2008. www.cdc.gov/hicpac/pdf/guidelines/ Disinfection_Nov_2008.pdf. 